\author{
Professor Gheorghe ZAMAN, PhD \\ Corresponding Member of Romanian Academy (Corresponding author) \\ E-mail: gheorghezaman@ien.ro \\ Romanian Academy, Institute of National Economy \\ Scientific Researcher Anamaria - Cătălina RADU, PhD \\ E-mail: anamaria_radu15@yahoo.com \\ Romanian Academy, Institute of National Economy \\ Senior Researcher II ${ }^{\text {nd }}$ degree, Ivona RĂPAN, PhD \\ E-mail: stradivonas@gmail.com \\ Romanian Academy, Institute of National Economy \\ Associate Professor Florian BERGHEA, PhD \\ E-mail: berghea1@gmail.com \\ University of Medicine and Pharmacy "Carol Davila" Bucharest
}

\title{
NEW WAVE OF DISRUPTIVE TECHNOLOGIES IN THE HEALTHCARE SYSTEM
}

\begin{abstract}
The Healthcare Industry had significantly improved in the last years due to the enhancement of the new technologies from the field. Experts from this branch believe that the emergence of these disruptive technologies in the Healthcare field can decrease the services' cost, can improve their quality and can provide benefits to patients in terms of convenience. The quantitative study carried out at the level of this paper aimed to determine the perception of medical professionals regarding the importance of modern technologies. The target is to analyze how respondents are familiar with mHealth Apps, IoT, AI and AR. We made the statistic analysis within this study based on a regression model. The study was conducted on a number of 241 respondents. The data analysis was made with the help of the SPSS software.

Keywords: healthcare system, disruptive technologies, quantitative research, web technologies.
\end{abstract}

JEL Classification : M31, O14, C10

\section{Introduction}

Information and communications technology (ICT) is based now on the disruptive technologies which are composed from the bond between the hardware and the software. "Information technology is the engine of globalization that facilitates the exchange of information between nations, corporations and

DOI: $10.24818 / 18423264 / 55.1 .21 .08$ 
individuals around the globe and creates an interconnected economy." (Preda, 2017)

The great amount of information, and we can refer metaphorical to an information war, is the center of the worldwide progress along with the development of the industry 4.0. Big data is stored on servers using smart technologies and contributing day by day to the humanity progress. "The environment is characterized by some natural activities, economic, social and political involve all participants equally and may include demographic data, lifestyle and economic cycles." (Rusanescu, 2018)

In order to better understand the way in which disruptive technologies have evolved, we have to identify the main stages these have went through over time. Thus, the Semantic web has progressively evolved, beginning from stage one, highlighted by the classic Web and finally reaching the Semantic Web. The main steps covered in the evolution of the Semantic Web were (De Pelsmacker, Geuens, Van den Bergh, 2010, p.20): the classic web, web services, ontologies, agencies and the semantic web. The first stage in this process is represented by the classic Web, familiar to everyone. It presents the raw information, which can only be processed by one person. It represents the foundation of the Semantic Web, incorporating the basic protocols (HTTP, HTML, XML, etc.). (Thuraisingham, 2002, p.24). Web services are the first step towards the notion of computerprocessable web. They allow computers to access information available on the Web in a standardized way (Pollock, 2009, p.10). Ontologies are the key to defining software that can understand and interpret information on the Web, which has the role of solving the problems of semantic interoperability that occur between various applications and services. (Taye, 2010, pp.184). These ontologies provide a useful means of annotating and classifying classified information on the Web. An ontology allows the structuring of information as a knowledge base. Ontologies are used to represent knowledge and to provide an official basis for the reasoning of this knowledge. Without ontologies, there are only collections of unstructured information (Walton, 2007, p.239).

Agents are essential for defining smart software on the Semantic Web, being software that acts autonomously on behalf of people. Therefore, these agents will be responsible for the automatic collection and exchange of knowledge on the Semantic Web. Individual agents are autonomous and rational, having the ability to interact by communicating with other agents. Semantic Web Services provides the means to build applications on the Semantic Web. These applications are composed of services that encapsulate agents, thinking systems and knowledge bases. The construction of the Semantic Web is an ongoing process, and the vision of the Semantic Web has not yet been fully realized. Building a Semantic Webspecific application does not involve applying all of the aspects described above, with each application requiring a subset of these techniques. For instance, Semantic Web applications can be built at purely ontological levels (Visser, 2005), using queries or reasoning, without the need for services or agents. Thus, a key-problem 
New Wave of Disruptive Technologies in the Healthcare System

in the application building is choosing the proper technologies through a careful analysis of the alternatives (Walton, 2007, pp. 236-238).

Passin (2004) mentioned that the Semantic Web is the one that offers the potential for data retrieved from the Internet to be known not only by humans but also by computers. Thus, both humans and computers have to interpret data (Roebuck, 2011, p.10) from the online environment and offer effective solutions for various problems (Yu, 2006). Kashyap, Bussler si Moran (2008) mentioned that the Semantic Web increases the interoperability between different informational systems and provide the capability of automatization for an increased number of systems. The role of Semantic Web is to apply technologies based on extensive knowledge with the purpose of filling the gap between human and machine. This aspect implies providing knowledge in formats that computers can process rapidly. (Mika, 2007, p.9). Moreover, the role of Semantic Web is to support the communication, coordination and cooperation process between humans (Cardoso, Hepp, Lytras, 2008). In the healthcare industry, in the last years, the doctors used the disruptive technologies to a better communication with their patients. The disruptive technologies offered them also the possibility to receive a direct response, and to interact with the end user. Moreover, the doctors use the online devices to follow some courses or the learn how to use different devices. A lot of authors mentioned that "we need to consider the computer assisted learning as one of the important directions of teaching and learning strategies modernization. According to the "pyramid of learning" the best method to design learning materials and deliver content through online courses is "learning by doing", although it isn't most effective (only 75\% compared to 90\%)." (Smeureanu, Isăilă, 2017).

Also, we can find a growth on the interest in apps and software dedicated to cover a certain need, people want to simplify their lives and they are moving towards online technologies such as mobile, cloud computing, Internet of Things, artificial intelligence, robots and robots process automation. Globally speaking, going mobile is the easiest way to be connected to everything, weather is about the job or the personal live. In the last year, in Romania, according to online shops, it has been registered a growth of demand for smart devices, smartphones, smart TV, phone tablet and other smart devices. There is a very strong need of individuals to be mobile, to use portable devices in medicine and the healthcare system especially, where patients and doctors have to be always connected. Cloud computing is another important part of the internet (Misra, S., Mondal, A., 2011) because it allows doctors to access an almost unlimited power of calculation, without major investments in the infrastructure. Regarding the existing cloud models, there can be 4 models defined: private, public and hybrid, but also the cloud for the community, each of them having a series of advantages and disadvantages (Zainuddina et al., 2015). The public cloud is considered profitable from the point of view of costs and it's implemented by large companies, public or governmental institutions, but also by small developing companies

DOI: 10.24818/18423264/55.1.21.08 
(Dumitrache,2014). The services models available at this moment in cloud are: SaaS (Software as a Service), PaaS (Platform as a Service) and IaaS (Infrastructure as a Service) (Greavu-Șerban, 2015, p. 44):

The driven for going mobile is to be continuous linked to different apps using dedicated technologies and software. A very important case study could be the convergence of online technologies that can give the disease's history of a patient in real time when he is consulting in the medial room. The medical doctor could create a digital recipe and the patient could be identified using Near Field Communication technology when buying the drugs from the pharmacy. The future is near, because all web technologies interlock and there aren't barriers between fixed and mobile devices anymore, the final consumer is using exclusively portable and dedicated smart technology devices (Klintworth, 2016). Linked to these dedicated devices, in the healthcare system, the IoT (Internet of Things) is a concept through which interconnected objects (wireless or not) can interact or cooperate pursuing to reach a common and shared scope. The concept IoT was invented by the British Kevin Ashton in 1999, who suggests an advanced interconnectivity between devices via communication protocols that use the already existing infrastructure (Vermesan and Friess, 2013). From the applications that IoT can have we remind: heart monitoring systems, biochip implants, electric seashells in the sea water, cleaning robots, unmanned aerial vehicle (drones) for surveillance the mental sick disorders patients etc. (Mattern and Floerkemeier, 2010).

In 2016, the global digital health market has been evaluated at approximately 179.6 billion USD. Until 2025 a growth of this market is expected to be registered, experts mentioning that it will reach 536.6 billion USD. The medical services' digitalization will bring substantial benefits in the following decade; thus, many people will have access to medical assistance regardless of their location. Currently, the digital health market comprises two important parts, which are: the healthcare information systems and wearable devices. The first component presents the greatest importance, many hospitals and clinics having computing systems via which they store all of the patients' medical in-formation (transparencymarketresearch.com). A study carried out in the healthcare field has revealed that disruptive technologies can have the following effects: the decentralization of the healthcare system and the knowledge transfer. Analyzing from the decentralization perspective must be noted that the applications' development that are based on the new disruptive technologies will generate among time the possibility of taking care of the ill from hospitals in various clinics, specially made buildings or even at the patients' residences.

The knowledge transfer illustrates that the new technologies will facilitate their transfer from the qualified medical personnel (expensive from the provided services viewpoint), towards certain more accessible providers or towards specific applications capable of identifying medical issues and in some cases even solving them. If we have to analyze the impact of the IoT technology on the healthcare 
New Wave of Disruptive Technologies in the Healthcare System

field, we can mention that the new applications allow health professionals to obtain in-formation regarding the health status of their patients (medical tests, blood pressure, body temperature, glucose level or respiratory rate) although they are at their homes. Portable devices that possess IoT technology have started to be increasingly utilized by the seniors. These devices permanently store details regarding the patient's status, his evolution as well as changes that occur.

Machine learning and Artificial intelligence (AI) help doctors in establishing diagnoses. These technologies have the capacity of analyzing a series of electronical health sheets, identify the patient's issue and present a series of recommendations. AI does not replace the health professionals, as it comes in their support, providing them rapid and complete information regarding different medical issues as well as the recommended treatment for their patients. Augmented Reality (AR) can be utilized to provide surgeons crucial information when they per-form simple or more complex medical interventions. By using this disruptive technology, surgeons will have the possibility of introducing the patients' MRI or CT into an AR headset and thus an over-laying of these with the human body and having the possibility to see the muscles, bones, internal organs without performing a surgery (emergency-live.com). Robots are considered a different type of disruptive technology. They began to be used in specific countries within the surgeries that require a high precision. Another disruptive technology used in the healthcare system is the 3D printing. For example, it is used to produce dental impressions for crowns, in the cases in which a perfectly fit restoration can be made (siliconrepublic.com).

Smartphones' use has brought a series of benefits for the patients that require medical assistance as well. Thus, they have the possibility to contact the doctors faster and receive a consultation although they are at home. Moreover, applications that are based on disruptive technologies allow people to permanently analyze their health status and be aware of the possible problems that may occur. According to the last made research from the healthcare field, the global life expectancy both for women and men will increase with 4.4 years until 2040, a significant role in it being played by the disruptive technologies from the field (health.com). "The advantages of online communication are multiple: it provides a great volume of information, it has an interactive character, and the information can be used at any time." (Radu, Tascu, Stoica, Radu, Purcarea, 2017)

\section{The impact of disruptive technologies at the level of various industries}

In order to better understand the role of disruptive technologies in the healthcare industry, we have analyzed the way in which the new disruptive industries have evolved over time at the global level. Our aim was on one side to observe the sums that were invested in the recent years in these technologies, as well as the outcomes that were obtained following their implementation. The technologies' Industry 4.0 (Internet of Things (IoT), Artificial Intelligence 3D

DOI: $10.24818 / 18423264 / 55.1 .21 .08$ 
Printing, Augmented Reality, Industrial Robots, Industrial Metrology, Blockchain, Digital Twin, 5G) were estimated at a value of 71.7 billion dollars in 2019 . According to the research carried out it is expected for this industry to notice a rapid growth and reach the value of 156.6 billion dollars in 2024 (marketsandmarkets.com). The advancement of disruptive technologies within Industry 4.0 will determine the fast development of the healthcare sector at the global level. Thus, the disruptive technologies that are part of this industry will determine the emergence of several innovative services for patients, the capability of fast and effective patient data analysis, sensor development for early detection for different diseases, IoT technology-based systems for patients, development of certain high-performance Imaging Systems, as well as the development of some high-performance robots for surgeries. (Javaid and Haleem, 2019)

Regarding the investments made in Artificial Intelligence (AI), it has to be mentioned that in 2019 there have been approximately 82.4 billion dollars assigned (statista.com). If we have to analyze the way in which these investments have been divided between the main systems that are based on artificial intelligence, it can be noticed that 14.4 billion dollars were invested in machine learning platforms, while a double sum has been assigned for the development of applications that are based on the machine learning technology. As it can be noticed from the table below, if approximately half of the investments made in AI systems (42 billion dollars) were assigned towards machine learning, the other half was assigned towards the other automated systems. The investments made in Smart Robots and the ones in computer vision platforms were in 2019 of 7.5 billion dollars, respectively 7.4 billion dollars, while the ones made in natural language processing and Computer vision applications have exceeded 6 billion dollars. The sums assigned towards the development of recommendation engines type systems have reached the value of 4.4 billion dollars in 2019, while the investment budget assigned for virtual assistants and speech recognition was of 2.9 billion dollars, respectively 2.4 billion dollars. Lower investments have been made for gesture control systems (1.1 billion dollars) respectively towards those of video recognition ( 0.7 billion dollars) (Feldman, 2019).

Table 1. Machine learning tops artificial intelligence

\begin{tabular}{lc}
\hline Machine Learning Tops AI & $\begin{array}{c}\text { AI funding worldwide } \\
\text { cumulative through March 2019 by } \\
\text { category (Billion USD) }\end{array}$ \\
\hline Machine learning applications & $\$ 28.5$ \\
\hline Machine learning platforms & $\$ 14.4$ \\
\hline Smart robots & $\$ 7.5$ \\
\hline Computer vision platforms & $\$ 7.4$ \\
\hline Natural language processing & $\$ 6.7$ \\
\hline Computer vision applications & $\$ 6.5$ \\
\hline Recommendation engines & $\$ 4.4$ \\
\hline
\end{tabular}


New Wave of Disruptive Technologies in the Healthcare System

\begin{tabular}{ll} 
Virtual assistants & $\$ 2.8$ \\
\hline Speech recognition & $\$ 2.4$ \\
\hline Gesture control & $\$ 1.1$ \\
\hline Video recognition & $\$ 0.7$ \\
\hline
\end{tabular}

Source: Feldman, 2019

The research made for 2020 have pictured that the expenses for AI-based systems will exceed 40 billion dollars at the global level. The greatest investments will be made in the banking industry, energy and transport utilities. If we have to analyze these expenditures isolated, at the level of each industry by itself, it can be observed that the banking industry will use approximately 12 billion dollars for the implementation of AI-based systems, the ones in the manufacturing sector will invest 9.5 billion dollars, while in the retail they will invest 9.3 billion dollars. For the development of public services by implementing some AI-based systems there will be 8.9 billion dollars assigned, while for the healthcare industry there will be approximately 5.3 billion dollars spend for the establishment of certain systems that are based on disruptive technologies (atos.net).

Table 2. Forecast for the projected artificial industry spending by industry for 2021

\begin{tabular}{lc}
\hline \multicolumn{1}{c}{ Industries } & Spending (Billion USD) \\
\hline Banking, financial services and insurance & $\$ 12$ \\
\hline Manufacturing & $\$ 10$ \\
\hline Retail & $\$ 9$ \\
\hline Public sector & $\$ 9$ \\
\hline Healthcare & $\$ 5$ \\
\hline
\end{tabular}

Source: atos.net

As we could previously observe, the investments made in smart robots have reached the threshold of 7.5 billion dollars in 2019, the assigned sum being much higher than the one dedicated to the other technologies on the market. The quite big investments made in this industry have automatically led to the increase of the number of manufactured and sold robots at the global level. A research conducted at the global level has illustrated that currently there are five markets at the global level that are making the $73 \%$ of the total volume of robot sales. These are: China: Japan, South Korea, USA and Germany. If in 2009 the total robots' sales has reached 60000 units globally, these have considerably grew until 2016 $(+390 \%)$, reaching the value of 294000 units. In 2017, the sales have increased with $30 \%$ comparing to the previous year, reaching the value of 381000 units, while in 2018 it is estimated that these have grew with 10\% reaching 421000 units. According to the forecasts made, it is estimated that until 2021 the total volume of industrial robots' sales will reach 630000 units (Shaw, 2018). 
Gheorghe Zaman, Anamaria-Cătălina Radu, Ivona Stoica (Răpan), Florian Berghea

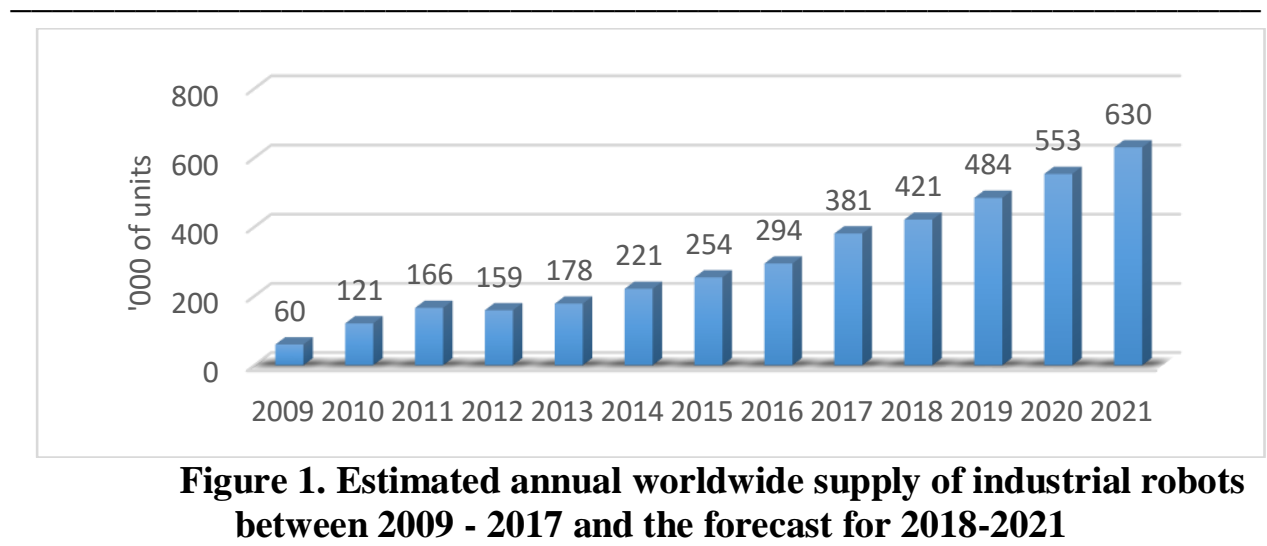

Based on the total sales' volume from the recent years, we wanted to observe the evolution of stocks in what regards the manufactured robots as well. Thus, if in 2008 the registered stock was of 1035000 units, it has grown with 57\% by 2015, reaching the value of 1632000 units (International Federation of Robotics, 2018). As shown in Figure 2, the operational stock of industrial robots has recorded a slightly increase since 2010 with 1.059 units of industrial robots, being expected to reach the peak in 2020 with more than 3.000 units, showing an increase of $+14 \%$ on average per year. The most significant growth in the robots' stock has been registered in $2016(+12 \%$ comparing to 2015), when the total number of robots has reached 1828000 units. According to the global level predictions it is expected that by 2020 the total value of industrial robots to overcome 3 million units. The development of disruptive technologies will gradually make its mark on the labor force, because some companies will drop human resources that they detain at this moment detrimental to robots.

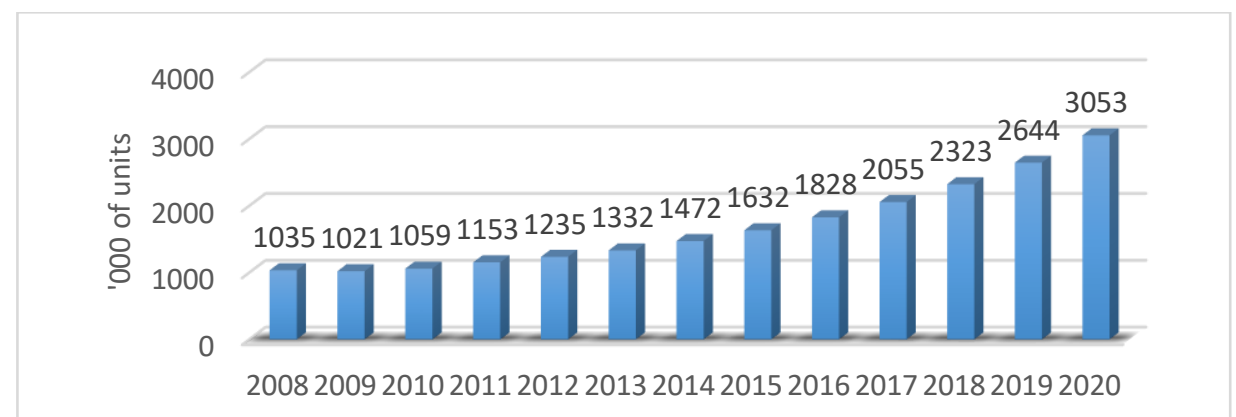

Figure 2. Estimated worldwide operational stock of industrial robots 20152016 and forecast for 2017-2020

A research conducted at the global level illustrated that the rapid evolution of disruptive technologies such as AI and robotics could lead to the loss of 73 million jobs in the US by 2030. According to these studies, this loss should not be seen as a disadvantage because leading to a growth of productivity, the economy 
New Wave of Disruptive Technologies in the Healthcare System

and increasing different industries. This will lead to massive changes in the labor market, considering that $1 / 3$ of the US workforce should retrain in other areas of activity (McCarthy, 2017). The rapid development of disruptive technologies will not only affect the US market, but also other markets. Thus, most of the lost jobs are expected to be registered in China (236 million) and India (120 million). It is estimated that the implementation of disruptive technologies in Japan will gradually lead to the loss of over 30 million jobs. Moreover, it is expected that lower losses will be registered in Mexico and Germany, 18 million jobs, respectively 17 million jobs. According to global studies, the most affected jobs will be those in the fast food sector but also in machinery operators. Jobs that will have higher stability are those in the management, engineering or education sector (McCarthy, 2017).

Table 3. Potential number of displaced jobs due to automation by 2030

\begin{tabular}{lc}
\hline Country & Million \\
\hline China & 236 \\
\hline India & 120 \\
\hline United States & 73 \\
\hline Japan & 30 \\
\hline Mexico & 18 \\
\hline Germany & 17
\end{tabular}

Source: McCarthy, 2017

As we mentioned at the beginning, it is very important to observe both the investments that have been made in recent years in the disruptive technologies currently existing on the market and the revenues collected from their implementation. A global study illustrated that \$ 8,097.9 million was obtained from static image recognition, classification, and tagging. Algorithmic trading strategy performance improvement technology brought in revenues of $\$ 557.4$ million lower between 2016 and 2025 while efficient, scalable patient data processing accumulated revenues of $\$ 7,366.4$ million. Revenues from content distribution on social media and those obtained from technology object detection and classification - avoidance, navigation exceeded 3 billion dollars in the period 2016-2025 (Armstrong, 2016).

Table 4. Forecasted cumulative global AI revenue 2016 - 2025

\begin{tabular}{lc}
\hline \multicolumn{1}{c}{ Case } & Million USD \\
\hline $\begin{array}{l}\text { Static image recognition, classification and } \\
\text { tagging }\end{array}$ & $\$ 8097.9$ \\
\hline $\begin{array}{l}\text { Algorithmic trading strategy performance } \\
\text { improvement }\end{array}$ & $\$ 7540.5$ \\
\hline Efficient, scalable processing of patient data & $\$ 7366.4$ \\
\hline $\begin{array}{l}\text { Predictive maintenance } \\
\text { Object identification, detection, classification, }\end{array}$ & $\$ 4680.3$ \\
\hline
\end{tabular}

DOI: 10.24818/18423264/55.1.21.08 
Gheorghe Zaman, Anamaria-Cătălina Radu, Ivona Stoica (Răpan), Florian Berghea

\begin{tabular}{l}
\hline \begin{tabular}{l} 
Text query of images \\
\hline Automated geophysical feature detection
\end{tabular} \\
\hline Content distribution on social media \\
\hline $\begin{array}{l}\text { Object detection and classification- } \\
\text { avoidance, navigation }\end{array}$ \\
\hline Prevention against cybersecurity threats \\
\multicolumn{3}{c}{ Source: Armstrong, 2016 } \\
3. Materials and Methods \\
3.1. Research sample \\
Within this study we intend to identify the health professionals' perception \\
regarding the importance of the new technologies in the activity they carry out as \\
well as the way in which these could influence their decisions. In order to collect \\
data an online survey was made and lately distributed to the respondents. The \\
snowball sampling method was used within this research. The quantitative study \\
was made in 2019 on a sample of 241 health professionals from Romania. From \\
which 77.6\% were under 40 years old, while 22.4\% of the respondents were \\
between $40-50$ years old. $47.7 \%$ of the health professionals that participated were \\
men, while $52.3 \%$ were women. $77.6 \%$ of the individuals that participated at the \\
study work in the urban area, while $22.4 \%$ of them work in the rural area.
\end{tabular}

Table 5. Sample structure

\begin{tabular}{|c|c|c|c|c|c|c|c|}
\hline \multicolumn{2}{|c|}{ Characteristics } & $\mathbf{N}$ & $\%$ & \multicolumn{2}{|c|}{ Characteristics } & $\mathbf{N}$ & $\%$ \\
\hline \multirow{2}{*}{$\begin{array}{l}\text { Respondent } \\
\text { age }\end{array}$} & $\begin{array}{c}<40 \\
\text { years } \\
\text { old }\end{array}$ & 187 & $77.6 \%$ & \multirow{2}{*}{$\begin{array}{l}\text { Respondent } \\
\text { gender }\end{array}$} & Male & 115 & $47.7 \%$ \\
\hline & $\begin{array}{c}26-35 \\
\text { years } \\
\text { old }\end{array}$ & 54 & $22.4 \%$ & & Female & 126 & $52.3 \%$ \\
\hline
\end{tabular}

Source: Statistical survey made by the authors

The modern technologies analyzed in this study are: mHealth Apps, IoT, $\mathrm{AI}$ and AR. We made the statistics analysis within this study based on the multiple linear regression equation, in which the dependent variable is represented by the total perception regarding the importance of the modern technologies in the carried out activity, while the independent variables (hereinafter predictor variables) were represented by the main technologies that are currently used in medicine.

3.2. Regression model

In what regards the conducted statistics analysis, in the table below the value of the coefficient of determination $\mathrm{R}$ Square can be noticed. $50.4 \%$ of the health professionals' perception regarding the importance of modern technologies in the carried-out activity variation is explained by the independent variables. 
New Wave of Disruptive Technologies in the Healthcare System

Table 6. Multiple linear regression model

\begin{tabular}{lc}
\hline Indicators & Results \\
\hline $\mathrm{R}$ & $.710 \mathrm{a}$ \\
\hline R Square & .504 \\
\hline Adjusted R Square & .496 \\
\hline Std. Error of the Estimate & 1.443 \\
\hline R Square Change & .504 \\
\hline F Change & 60.051 \\
\hline df1 & 4 \\
\hline df2 & 236 \\
\hline Sig. F Change & .000
\end{tabular}

The multiple linear regression equation conducted within this analysis is valid, as the value of the Sig. Term from Table 2 is lower than 0.05 $(\mathrm{p}=0.000<0.05)$.

Table 7. Multiple linear regression model- ANOVA

\begin{tabular}{llcccc}
\hline & $\begin{array}{c}\text { Sum of } \\
\text { Squares }\end{array}$ & df & Mean Square & F & Sig. \\
\hline Regression & 500.492 & 4 & 125.123 & 60.051 & $.000^{\mathrm{b}}$ \\
\hline Residual & 491.732 & 236 & 2.084 & & \\
\hline Total & 992.224 & 240 & & & \\
\hline
\end{tabular}

From the table below can be observed that the value of Sig. associated to devices based on the AR technology $<0.05$, which suggests that this variable won't be taken into account in the multiple linear regression model.

Table 8. Multiple linear regression model

\begin{tabular}{|c|c|c|c|c|c|}
\hline \multirow{2}{*}{ Model } & \multicolumn{2}{|c|}{$\begin{array}{l}\text { Unstandardized } \\
\text { Coefficients }\end{array}$} & \multirow{2}{*}{$\begin{array}{c}\begin{array}{c}\text { Standardized } \\
\text { Coefficients }\end{array} \\
\text { Beta }\end{array}$} & \multirow[t]{2}{*}{$\mathrm{t}$} & \multirow[t]{2}{*}{ Sig. } \\
\hline & B & Std. Error & & & \\
\hline (Constant) & 0.435 & 0.428 & & 1.015 & 0.311 \\
\hline $\begin{array}{l}\text { mHealth } \\
\text { Apps }\end{array}$ & 0.274 & 0.047 & 0.326 & 5.811 & 0 \\
\hline $\begin{array}{l}\text { Devices } \\
\text { based on the } \\
\text { IoT }\end{array}$ & 0.343 & 0.071 & 0.301 & 4.831 & 0 \\
\hline $\begin{array}{l}\text { Devices } \\
\text { based on the } \\
\text { AR }\end{array}$ & -0.028 & 0.036 & -0.036 & $\begin{array}{c}- \\
0.779\end{array}$ & 0.436 \\
\hline $\begin{array}{l}\text { Devices that } \\
\text { use AI }\end{array}$ & 0.247 & 0.062 & 0.228 & 3.995 & 0 \\
\hline
\end{tabular}

DOI: 10.24818/18423264/55.1.21.08 
Gheorghe Zaman, Anamaria-Cătălina Radu, Ivona Stoica (Răpan), Florian Berghea

In what regards the multiple regression model equation, it is defined as:

$\mathrm{Y}=\mathrm{a}+\mathrm{b} 1 * \mathrm{X} 1+\mathrm{b} 2 * \mathrm{X} 2+\mathrm{b} 3 * \mathrm{X} 3+\varepsilon$, where:

$\mathrm{Y}$ - represents the dependent variable;

$\mathrm{a}$ - represents the origin point of the line (Constant);

b1, b2, b3 - represent the b coefficients for the independent variables;

$\mathrm{X} 1, \mathrm{X} 2, \mathrm{X} 3$ - represent the estimated value of the model's variables;

$\varepsilon$ - represents the standard error for the estimation.

Table 9. Multiple linear regression model - Coefficients

\begin{tabular}{lccccccc}
\hline & \multicolumn{2}{c}{$\begin{array}{c}95.0 \% \text { Confidence } \\
\text { Interval for B }\end{array}$} & \multicolumn{2}{c}{ Correlations } & \multicolumn{2}{c}{$\begin{array}{c}\text { Collinearity } \\
\text { Statistics }\end{array}$} \\
\cline { 2 - 9 } & $\begin{array}{l}\text { Lower } \\
\text { Bound }\end{array}$ & $\begin{array}{c}\text { Upper } \\
\text { Bound }\end{array}$ & $\begin{array}{c}\text { Zero- } \\
\text { order }\end{array}$ & Partial & Part & Tolerance & VIF \\
\hline $\begin{array}{l}\text { (Constant) } \\
-0.409\end{array}$ & 1.279 & & & & & \\
\hline $\begin{array}{l}\text { mHealth } \\
\text { Apps }\end{array}$ & 0.181 & 0.367 & 0.594 & 0.354 & 0.266 & 0.667 & 1.5 \\
\hline $\begin{array}{l}\text { Devices } \\
\text { based on } \\
\text { the IoT }\end{array}$ & 0.203 & 0.482 & 0.618 & 0.3 & 0.221 & 0.54 & 1.853 \\
$\begin{array}{l}\text { Devices } \\
\text { based on } \\
\text { the AR }\end{array}$ & -0.1 & 0.043 & - & -0.051 & -0.036 & 0.997 & 1.003 \\
\hline $\begin{array}{l}\text { Devices } \\
\text { that use } \\
\text { AI }\end{array}$ & 0.125 & 0.369 & 0.541 & 0.252 & 0.183 & 0.646 & 1.548 \\
\hline
\end{tabular}

4. Results and Discussion

According with the results that we obtained, the multiple linear regression equation is:

The health professionals' perception regarding the importance of modern technologies in the carried out activity =

$0.326 *$ mHealth Apps $+0.301 *$ Devices based on IoT technology $+0.228 *$ Devices that use AI +1.443

In what regards the research limits, it has to be mentioned that the research was conducted on a number of 241 health professionals, which does not allow us the extrapolation of the results over the entire studied collectivity. In order to get a clear image on the analyzed subject, we consider that in the future there have to be other studies made, on a larger number of health professionals that would detailed 
New Wave of Disruptive Technologies in the Healthcare System

present the way in which the new technologies have the capacity to ease the fast identification of diagnoses and treatments. Moreover, the survey that was distributed online and, in this way, we don't have the certitude that it has been completed only by the health professionals towards it was transmitted. Within this analysis we have focused only of a part of the modern technologies that have the capacity to improve the activity carried out by health professionals. In the future, we consider that more detailed studies should be made that would analyze a much wider range of modern technologies that have the capacity to ease the activity carried out by health professionals in various activity fields.

On the other hand, the research was conducted on a number of 241 health professionals, which does not allow us the extrapolation of the results over the entire studied collectivity. In order to get a clear image on the analyzed subject, we consider that in the future there have to be other studies made, on a larger number of health professionals that would detailed present the way in which the new technologies have the capacity to ease the fast identification of diagnoses and treatments. Another limit of the research refers to the survey that was distributed online and, in this way, we don't have the certitude that it has been completed only by the health professionals towards it was transmitted. Within this analysis we have focused only of a part of the modern technologies that have the capacity to improve the activity carried out by health professionals. In the future, we consider that more detailed studies should be made that would analyze a much wider range of modern technologies that have the capacity to ease the activity carried out by health professionals in various activity fields.

\section{Today's innovations, tomorrow's global health}

With the emergence of delicate medical situations and the process of retechnologization and initiation of new medical technologies to restore the anatomical functions of the human body and even life, new techniques and medical tools have been developed and deployed for tests.

Against the background of the appearance of Covid-19 but also until this global pandemic event, the researchers looked for answers to questions through various innovative technologies tested and developed in the medical field.

McKinsey Global published in July 2020, a report on the innovations referring to the global medical system. The report is called Prioritizing health: A prescription for prosperity (Mckinsey, 2020) with impact for the year 2040. The innovations described in this report are technological research initiatives still in tests but with high chances of successful because it is appreciated a reduction between $6 \%-10 \%$ of diseases or to prevent the onset of chronic, heredodegenerative, genetic or acquired diseases.

In the last few months, in this global pandemy, the medical sector has focused on two important directions: therapy and vaccine. Here are a few technologies that could contribute to global health.

DOI: 10.24818/18423264/55.1.21.08 
Being part of the Bio Revolution, omics and molecular technologies identify types of molecules within cells that harm the body. An example is the genome editing, a molecular engineering technology.

Another example is coming from the next generation pharmaceuticals. Senolytics is a class of small molecules that may slowdown or eliminating the aging cells guilty for tissue damage or dysfunction at aged individuals.

A very interesting and effective research was done on the cellular therapy and regenerative medicine used to replace or to repair damaged cells or tissues, together those can restore the organs avoiding reliance or transplantation. An example is the CAR T-cell therapy that reprograms the immune-system cells, Tcells, to identify, attack and destroy the tumour cells.

The R\&D medical researchers in innovative vaccines discovered the AT04A vaccine that lowers the cholesterol by binding to blood cholesterol and degrade it. A very easy method and one a year is enough to control the lipid level.

"Tracking the new technologies in which regards the advanced surgical procedures like suspended animation for severe-trauma patients. Without resuscitation the medical doctor injects to the patient a cold saline solution to cool the body's temperature and stop its functions. This give time for the surgeon." (Remes et al., 2020)

Another proof of great benefits form developing industry 4.0 are the portable, wearable and ingestible or implantable devices for monitoring health of patients and to deliver self-regulated therapies autonomously. For example, ultrathin e-tattoos for heart diagnostics to provide a wider range of data, electroceuticals - "therapies map neural circuitry with neural impulses implantable device, microchips to mitigate chronic pain avoiding opioid and painkillers, by stimulating spinal cord, increasing this way the mobility patient, enhancing sleep reducing the need to lower the pain." (Remes et al, 2020)

Robotics and prosthetics is a sector in course of development to replace or artificial substitute body parts using self-controlled devices. An example is the next generation exoskeletons and mobility support, small motors that reproduce one-toone the mobility of the human muscle, recovering the autonomy of injured patients.

An Artificial Intelligence app now can change behaviors in a broad spectrum of physical and mental conditions by using a software. These are digital therapeutics powered by AI that support the patients to have a healthy behaviour.

Multichannel care delivery ensure the continuity of the care for sick patients use online platforms that facilitate data sharing and making the treatment more efficient especially for chronical diseases like diabetes, hipercholestherolomy.

These are technologies and tools, innovations of the R\&D investment of pharma companies or medical and academia to improve the strengthen the health of individuals from the world and to increase the quality of life and the wellbeing. 
New Wave of Disruptive Technologies in the Healthcare System

\section{Conclusions}

The nascence of modern technologies has brought a series of benefits to the medical system. The study conducted within this paper had the purpose of determining the perception of health professionals from Romania regarding the importance of modern technologies in their carried-out activity. Thereby, we wanted to observe the opinion of the responders in which regards the influence of disruptive technologies over their activity and career.

Following the study, we have observed that the interviewees consider that these technologies have a great importance, the mobile applications being in the top. These give the health professionals the possibility to maintain the connection with the patients and record all of their symptoms. They have also considered the devices based on modern technologies such as: IoT and AI important, these having the role of reducing the time of determining diagnoses and facilitate the identification of treatments. In the future, we consider that these types of studies should be conducted at the level of various specializations to identify the way in which the new technologies have the capacity of facilitating the activity carried out by health professionals.

\section{REFERENCES}

[1] Armstrong, M. (2016), The Future Of A.I., Available online: https://www.statista.com/chart/6810/the-future-of-ai/ (accessed on 11.05.2020);

[2] De Pelsmacker, P., Geuens, M.,Van den Bergh, J. (2010), Marketing Communications - A European Perspective; Pearson Education, Harlow;

[3] Cardoso, J., Hepp, M., Lytras, M.D. (2008), The Semantic Web RealWorld Applications from Industry, Springer, New York;

[4] Dumitrache, M. (2014), Cloud Computing - O nouă etapă în dezvoltarea internetului; Revista Română de Informatică şi Automatică, 24 (4): 40-48;

[5] Feldman, S. (2019), Machine Learning Tops AI Dollars, Available online: https://www.statista.com/chart/17966/worldwide-artificial-intelligencefunding/ (accessed on 05.05.2020);

[6] International Federation of Robotics. (2018), Robots Double Worldwide by 2020, Available online: https://ifr.org/ifr-press-releases/news/robotsdouble-worldwide-by-2020 (accessed on 07.05.2020);

[7] Javaid, M., Haleem, A. (2019), Industry 4.0 Applications in Medical Field: A brief review; Current Medicine Research and Practice, 9(3): 102-109;

[8] Kashyap, V., Bussler, Ch, Moran, M. (2008), The Semantic Web Semantics for Data and Services on the Web, Springer, Berlin;

[9] Klintworth, A. (2016), Bridging the Gap Between the Mobile Web and Mobile Apps, Available online: https://theblog.adobe.com/bridging-gapmobile-web-mobile-apps/ (accessed on 11.04.2020);

DOI: 10.24818/18423264/55.1.21.08 
Gheorghe Zaman, Anamaria-Cătălina Radu, Ivona Stoica (Răpan), Florian Berghea

[10] Mattern, F., Floerkemeier, C. (2010), From the Internet of Computers to the Internet of Things, Springer, Berlin;

[11] McCarthy, N. (2017), Automation Could Eliminate 73 Million U.S. Jobs by 2030, Available online: https://www.statista.com/chart/12082/automation-couldeliminate-73-million-us-jobs-by-2030/ (accessed on 15.05.2020);

[12] Mika, P. (2007), Social Networks and the Semantic Web, Springer, New York;

[13] Misra, S.C., Modal, A. (2011), Identification of a Company's Suitability for the Adoption of Cloud Computing and Modelling its Corresponding Return on Investment; Mathematical and Computer Modelling, 53(3): 504-521;

[14] Passin, T.B. (2004), Explorer's Guide to the Semantic Web; Manning, USA; [15] Pollock, J. T. (2009), Semantic Web For Dummies; Willey Publishing, Hoboken;

[16] Preda, A.-L. (2017), The Moral and Spiritual Grounds of the Economic Crisis from the First Decade of the 21st Century. Studii și Comunicări/DIS, (10): 343-360;

[17] Radu, A.V., Tascu, A.V., Stoica, I., Radu, A.C., Purcarea,V. (2017), Online Instruments Used in Pharmaceutical Marketing, Farmacia, 65(2):317322;

[18] Roebuck, K. (2011), Web 3.0 - The Semantic Web: High-Impact Strategies - What You Need to Know: Definitions, Adoptions, Impact, Benefits, Maturity, Vendors, Emereo Pty Limited, Newstead;

[19] Rusanescu, C.-O., Jinescu, C., Rusanescu, M., Begea, M., Ghermec, O. (2018), Evaluation of Air Pollution by NO2, SO2, PM10 in Bucharest, Revista de Chimie, 69(1): 105-111;

[20] Shaw, K. (2018), Global Industrial Robot Sales Doubled over Last Five Years, Report Says, Robotics Business review, Available online:

https://www.roboticsbusinessreview.com/news/global-sales-for-industrial-robotsdoubled-over-last-five-years/ (accessed on 20.05.2020);

[21] Smeureanu, I., Isăilă, N.. (2017), Innovative Educational Scenarios in Game Based Teaching and Learning, Amfiteatru Economic Journal, 19 (46): 890890 ;

[22] Taye, M.M. (2010), Understanding Semantic Web and Ontologies: Theory and Applications, Journal of Computing, 2 (6): 182-192;

[23] Thuraisingham, B. (2002), XML Databases and the Semantic web, CRC Press $L L C$, Florida;

[24] Vermesan, O., Friess, P. (2013), Internet of Things: Converging

Technologies for Smart Environments and Integrated Ecosystems, River

Publishers, Aalborg;

[25] Visser, U. (2005), Intelligent Information Integration for the Semantic

Web, Springer, Berlin;

[26] Walton, C. (2007), Agency and the Semantic Web, Oxford University Press, Oxford; 
New Wave of Disruptive Technologies in the Healthcare System

[27] Yu, L. (2007), Introduction to the Semantic Web and Semantic Web Services, Taylor \& Francis Group, New York;

[28] Zainuddina, N., Nurazean, M., Wardah, Z.A., NurulHuda F. A., Ganthan N. S. (2015), Cloud Computing Adoption Conceptual Model of

Malaysian Hospitals, Open International Journal of Informatics (OIJI), 3(1): 1-10;

[29] https://www.marketsandmarkets.com/Market-Reports/industry-4-market-

102536746.html (accessed on 11.04.2020);

[30] https://atos.net/en/artificial-intelligence (accessed on 11.04.2020);

[31] https://www.transparencymarketresearch.com/digital-health-market.html (accessed on 11.04.2020);

[32] https://www.emergency-live.com/equipment/how-technology-disruption-ischanging-healthcare/ (accessed on 05.05.2020);

[33] https://www.siliconrepublic.com/machines/healthcare-emerging-technologies/ (accessed on 05.05.2020);

[34] https://www.health.com/mind-body/life-expectancy-2040/ (accessed on 05.05.2020);

[35] Remes, J., Linzer, K., Singhal, S., Dewhurst, M., Dash, P., Woetzel, J., Smit, S., Evers, M., Wilson, M., Rutter, K.-A., Ramdorai, A. (2020), Prioritizing Health: A Prescription for Prosperity, https://www.mckinsey.com/industries/healthcare-systems-and-services/ourinsights/prioritizing-health-a-prescription-for-prosperity. 